\title{
PENGELOLAAN ALOKASI DANA DESA DALAM PEMBERDAYAAN MASYARAKAT
}

\author{
*Sri Sapitri ${ }^{1)}$, Rinto Alexandro ${ }^{2)}$ \\ ${ }^{1,2)}$ Fakultas Keguruan dan Ilmu Pendidikan Universitas Palangka Raya, Indonesia \\ *Email Korespondensi : srisapitri@mhs.pascasarjana.upr.ac.id
}

\begin{abstract}
Abstrak
Pengelolaan Alokasi Dana Desa dalam Pemberdayaan Masyarakat. Alokasi dana desa adalah dana perimbangan keuangan pusat dan daerah yang diterima kabupaten/kota yang dibagikan secara proporsional kepada setiap desa dengan proporsi paling sedikit 10\% (sepuluh persen). Alokasi dana desa untuk penyelenggaraan pemerintahan desa dan pemberdayaan masyarakat. Penelitian ini menggunakan metode kualitatif dengan menggunakan deskriptif. Hasil penelitian menunjukkan bahwa secara normatif dan tata kelola dana alokasi desa sudah dilaksanakan dengan baik, namun secara substansi masih belum memenuhi makna pemberdayaan yang sebenarnya. Selain itu, beberapa pemangku kepentingan juga belum berperan maksimal, hanya kepala desa sebagai tim pelaksana yang mengelola dana alokasi desa. Masyarakat paternalistik masyarakat desa memilih orang-orang yang mempercayai dan mendukung desa untuk mengelola dana desa, serta mendominasi kecamatan dalam membuat surat pertanggungjawaban yang berujung pada peningkatan kemandirian desa.
\end{abstract}

Kata Kunci: Dana Desa ; Pemberdayaan ; Desa

\begin{abstract}
Village_Fund Allocation Management in Community Empowerment. Village fund allocations are central and regional financial balance funds received by regencies / cities, which are distributed proportionally to each village in a proportion of at least $10 \%$ (ten percent). Allocation of village funds for village governance and community empowerment. This research uses a qualitative method using descriptive. The results showed that normative and governance of village allocation funds were carried out well, but the substance still did not meet the true meaning of empowerment. In addition, some stakeholders also have not played a maximum role, only the village head as the implementation team that manages the village allocation funds. The paternalistic community of the village community chooses the people who trust and support the village to manage village funds, as well as dominating the sub-district in making accountability letters that lead to increased village independence.
\end{abstract}

Keywords: Village Finance; Empowerment; Village 


\section{PENDAHULUAN}

Negara Kesatuan Republik Indonesia telah mengatur keberadaan desa dalam UndangUndang Nomor 22 tahun 1999 yang telah direvisi melalui Undang-Undang Nomor 32 tahun 2004 tentang Pemerintahan Desa. Lebih lanjut Undang-Undang tersebut mengatur tentang keberadaan organisasi pemerintahan yang berada di desa. Kedepannya diharapkan setiap desa, supaya bisa melakukan proses pembangunan di daerahnya masing-masing dengan mengatur dan mengurus sendiri rumah tangganya. Salah satu hal mendasar yang menjadi urusan pemerintahan desa adalah urusan pemerintahan yang menjadi kewenangaan kabupaten/kota yang diserahkan pengaturannya kepada desa "(UU Nomor 72 tahun 2005). Pembangunan desa merupakan salah satu urusan yang menjadi kewenangan desa. Sebagai implikasi dari penyelenggaraan pembangunan tersebut, tentu saja akan membutuhkan pembiayaan atau sumber-sumber penerimaan desa. Salah satu sumber penerimaan desa yaitu dana perimbangan keuangan pusat dan daerah yang diterima oleh kabupaten/kota yang dalam pembagiannya untuk setiap desa dibagikan

Secara proporsional yaitu paling sedikit 10\% (sepuluh persen) yang disebut dengan alokasi dana desa. Selanjutnya, anggaran alokasi dana desa tersebut akan digunakan sebagai penunjang kegiatan otonomi desa agar dapat maksimal dalam memberikan pelayanan, pembangunan, serta pemberdayaan masyarakat ditingkat pedesaan. Oleh karena itu, jika anggaran tersebut dikelola secara baik dan jujur maka hasil kegiatan otonomi desa, khususnya pemberdayaan masyarakat akan terlihat jelas. Sehubungan dengan hal tersebut, dalam pelaksanaan pengelolaan alokasi dana desa peran serta masyarakat juga menjadi hal yang penting terutama dalam proses pengambilan keputusan dan pelaksanaan kegiatan yang menyangkut kebutuhan masyarakat desa. Selain itu, diperlukan juga adanya kerjasama yang baik antara aparatur desa dengan masyarakat dalam setiap tahapan-tahapan pengelolaan alokasi dana desa. Jika hal tersebut berjalan dengan baik makan besar kemungkinan masyarakat dapat lebih mengembangkan diri untuk mencapai kemajuan bersama seperti yang diharapkan dari program ini yaitu terciptanya masyarakat yang lebih berdaya. Selain melibatkan masyarakat, kegiatan pengelolaan alokasi dana desa juga turut melibatkan beberapa stakeholders seperti karang 
taruna, tim penggerak PKK, serta Badan Permusyawaratan Desa (BPD). Stakeholders tersebut diharapkan mampu untuk saling bekerja sama dalam pelaksanaan pengelolaan alokasi dana desa.

\section{TINJAUAN PUSTAKA}

\section{Administrasi Keuangan}

Menurut The Liang Gie (1987, h.18) administrasi keuangan diartikan sebagai suatu subkonsep atau tata keuangan sebagai suatu proses, yaitu rangkaian kegiatan penataan yang berupa penyusunan anggaran belanja, penentuan sumber biaya, cara pemakaian, pembukuan, dan pertanggungjawaban atas pembiayaan dalam kerjasama untuk mencapai tujuan tertentu. Sedangkan tujuan yang ingin dicapai oleh administrasi keuangan adalah pertanggung jawaban, efisiensi dan/atau efektivitas dalam pengadaan dana serta dalam penggunaan dana. Administrasi keuangan menerapkan fungsifungsi pokok manajemen pada umumnya. Salah satu fungsi manajemen yang sederhana dan dapat diterapkan dalam administasi keuangan adalah fungsi yang dikemukakan oleh Terry dalam Siagian (1990, h.105) yaitu fungsi Planning (Perencanaan), Organizing (Pengorganisasian), Actuating (Penggerakan atau Pelaksanaan), Controlling (Pengawasan) atau yang biasa disebut dengan P.O.A.C.

\section{Pemerintahan Desa}

Undang-Undang Nomor 32 tahun 2004 menyebutkan bahwa desa adalah kesatuan masyarakat hukum yang memiliki batas-batas wilayah yang berwenang untuk mengatur dan mengurus kepentingan masyarakat setempat, berdasarkan hak asal-usul dan adat istiadat setempat yang diakui dan dihormati dalam sistem pemerintahan Negara Kesatuan Republik Indonesia. Sedangkan pemerintah desa merupakan unsur penyelenggara pemerintah yang terdiri atas kepala desa dan perangkat desa. Dalam menjalankan tugastugasnya, pemerintah desa dipimpin oleh kepala desa dibantu oleh sekretaris desa dan perangkat desa yang terdiri atas kepalakepala urusan, pelaksana urusan, dan kepala dusun. Untuk mengatur dan mengurus urusannya, pemerintah desa membuat peraturan desa yang disusun oleh kepala desa bersama dengan Badan Permusyawaratan Desa (BPD). 


\section{Alokasi Dana Desa}

Menurut Rozaki dkk (2005, h.120) sesungguhnya kebijakan alokasi dana desa yang telah dijalankan memiliki tujuan besar yang kurang lebih sama yaitu merombak ortodoksi pemerintah kabupaten dalam memberikan kewenangan, pelayanan dan bantuan keuangan kepada pemerintahan di level bawahnya (desa). Pola kebijakan pemerintahan kabupaten yang semula dominan dan sentralis, melalui metode alokasi dana desa ini berubah menjadi partisipatif, responsif, dan dijalankan melalui asas desentralisasi. Alokasi dana desa merupakan bagian dari keuangan desa yang diperoleh dari bagi hasil pajak daerah dan bagian dari dana perimbangan keuangan pusat dan daerah yang diterima oleh kabupaten untuk desa paling sedikit $10 \%$ (sepuluh persen). Seluruh kegiatan yang berasal dari anggaran alokasi dana desa direncanakan, dilaksanakan, dan dievaluasi secara terbuka dengan melibatkan seluruh masyarakat desa.

\section{Pemberdayaan Masyarakat}

Menurut Adisasmita (2013, h.78) pemberdayaan masyarakat adalah upaya pemanfaatan dan pengelolaan sumber daya masyarakat perdesaan secara lebih efektif dan efisien, baik dari (a) aspek masukan atau input (sumberdaya manusia, dana, peralatan/sarana, data, rencana, dan teknologi; (b) dari aspek proses (pelaksanaan, monitoring, dan pengawasan); (c) dari aspek keluaran atau output (pencapaian sasaran, efektivitas, dan efisiensi). Tujuan pemberdayaan masyarakat menurut Sumaryadi (2005, h.25) pada dasarnya yaitu untuk membantu pengmbangan manusiawi yang otentik dan integral dari masyarakat yang lemah, miskin, marjinal dan kaum kecil serta untuk memberdayakan kelompok masyarakat tersebut secara sosio ekonomis sehingga mereka dapat lebih mandiri dan dapat memenuhi kebutuhan dasar hidup mereka namun sanggup berperan serta dalam pengembangan masyarakat. Menurut Elliot dalam Sumaryadi (2005, h.150) ada tiga strategi pendekatan yang dipakai dalam proses pemberdayaan masyarakat, antara lain: (a) the walfare approach yaitu membantu memberikan bantuan kepada kelompokkelompok tertentu, misalnya mereka yang terkena musibah bencana alam dan pendekatan ini tidak dimaksudkan untuk memberdayakan rakyat dalam menghadapi

proses politik dan kemiskinan rakyat, (b) the development approach, pendekatan ini memusatkan perhatian pada pembangunan peningkatan kemandirian, kemampuan, dan 
keswadayaan masyarakat, (c) the empowerment approach, pendekatan ini melihat kemiskinan sebagai akibat proses politik dan berusaha memberdayakan atau melatih rakyat untuk mengatasi ketidakberdayaannya.

\section{METODE PENELITIAN}

Penelitian ini menggunakan metode deskriptif dengan pendekatan kualitatif. Fokus dari penelitian ini yaitu:

1. Pengelolaan alokasi dana desa dalam pemberdayaan masyarakat

a. Perencanaan alokasi dana desa

b. Mekanisme penyaluran dan pencairan alokasi dana desa.

c. Pelaksanaan alokasi dana desa

d. Pengawasan alokasi dana desa

e. Pertanggungung jawaban alokasi dana desa

f. Transparansi alokasi dana desa

2. Peran stakeholders pada pengelolaan alokasi dana desa
a. Kepala desa
b. Karang taruna
c. Tim penggerak PKK
d. Masyarakat desa
e. Badan Permusyawaratan Desa (BPD)

3. Hasil-hasil pemberdayaan masyarakat dari anggaran alokasi dana desa
a. Pemberdayaan lingkungan
b. Pemberdayaan manusia

4. Faktor penghambat dan faktor pendukung pengelolaan alokasi dana desa

a. Faktor penghambat alokasi dana desa

b. Faktor pendukung alokasi dana desa

Lokasi penelitian yang dipilih adalah lokasi dan situs penelitian tersebut peneliti bisa mendapatakan sumber data primer maupun sekunder dengan cara wawancara dan dokumentasi. Penelitian ini menggunakan metode analisis model interakatif milik Miles dan Huberman yang terdiri dari reduksi data, penyajian data, dan penarikan kesimpulan. 


\section{HASIL DAN PEMBAHASAN}

\section{Pengelolaan Alokasi Dana Desa dalam Pemberdayaan Masyarakat}

Pengelolaan alokasi dana desa merupakan bagian yang tidak terpisahkan dari pengelolaan keuangan desa dalam Anggaran Pendapatan dan Belanja Desa (APBDes). Perlu diketahui bahwa alokasi dana desa bukan merupakan bantuan melainkan dana bagi hasil atau perimbangan antara pemerintah kabupaten/kota dengan desa sebagai wujud dari pemenuhan hak desa untuk penyelenggaran otonomi desa.

Sampai dengan tahun 2013, anggaran alokasi dana desa yang diterima oleh Pemerintah yaitu sebesar Rp. 41.500.000,- yang kemudian digunakan untuk biaya penyelenggaraan pemerintahan desa dan untuk biaya pemberdayaan masyarakat. dalam rangka mendukung kelancaran pelaksanaan pengelolaan alokasi dana desa, maka dibentuklah organisasi pengelolaa alokasi dana desa yang meliputi tim pembina tingkat kabupaten, tim pengendali tingkat kecamatan, dan tim pelaksana tingkat desa. Adapun pengelolaan alokasi dana desa Deket Kulon terdiri dari beberapa mekanisme yaitu:

Pertama, perencanaan awal dalam alokasi dana desa yang merupakan tahap paling awal dari kegiatan pengelolaan alokasi dana desa. Kegiatan perencanaan bertujuan untuk menyusun rencana kegiatan secara partisipatif sekaligus menetapkan alokasi anggaran yang dituangkan dalam Daftar Rencana Kegiatan (DRK). Setelah DRK tersusun, selanjutnya kepala desa selaku penanggung jawab membentuk tim pelaksana alokasi dana desa yang terdiri dari Pelaksana Teknis Pengelolaan Keuangan Desa (PTPKD) dan bendahara desa.

Kedua, penyaluran alokasi dana desa dilakukan setelah DRK alokasi dana desa yang telah disusun dan disepakati beserta lampiranlampiran kelengkapan administrasi disampaikan kepada camat untuk diteliti. Selanjutnya, secara kolektif camat menyampaikan kepada Badan Pemberdayaan Masyarakat(BPM dan diteruskan kepada Dinas Pendapatan, Pengelolaan Keuangan dan Asset (DPPKA) untuk diproses pencairaannya melalui PT. Bank Jatim cabang Lamongan. Pencairan anggaran alokasi dana desa dilakukan 2 (dua) tahap dalam setahun, yakni sebesar 50\% (lima puluh persen) pada tahap pertama dan sebesar 50\% (lima puluh persen) pada tahap kedua. 
Ketiga, pelaksanaan alokasi dana desa yang merupakan tahap realisasi dari seluruh rencana kegiatan pengelolaan alokasi dana desa yang telah disepakati. Alokasi dana desa yang diterima digunakan untuk biaya penyelenggaran pemerintah yang diserahkan pada masingmasing-masing pos dan untuk biaya pemberdayaan masyarakat diserahkan kepada tim pelaksana tingkat desa yang nantinya akan dipertanggungjawabkan kepada kepala desa. Pelaksana kegiatan tersebut meliputi kepala desa, karang taruna, tim pengerak PKK, Badan Permusyawaratan Desa (BPD), serta masyarakat desa.

Keempat, pengawasan alokasi dana desa yang diperlukan agar pelaksanaan tugas yang telah ditetapkan terhindar dari penyimpanganpenyimpangan. Pengawasan tersebut meliputi pengawasan langsung yang dilakukan oleh kepala desa kepada para tim pelaksana pengelolaan alokasi dana desa dan pengawasan tidak langsung yang berupa laporan tertulis yaitu Surat Pertanggung Jawaban (SPJ) alokasi dana desa. Disisi lain, pengawasan yang dilakukan oleh masyarakat desa masih belum nampak bahkan masyarakat cenderung tidak peduli dengan adanya program tersebut. Padahal pengawasan dari masyarakat sangat diperlukan untuk menghindari terjadinya kesalahan, penyeleweangan atau hal-hal lain yang tidak dinginkan.

Kelima, pertangungjawaban alokasi dana desa yang dilakukan secara administratif dalam bentuk Surat Pertanggung Jawaban (SPJ) dengan format keuangan yang sudah ditentukan dalam peraturan yang berlaku. Pertanggungjawaban tersebut merupakan wujud dari pertanggungjawaban administratif desa kepada pemerintah di atasnya, sedangkan pertanggung- jawaban pemerintah desa kepada masyarakat masih belum nampak.

Keenam, transparansi alokasi dana desa yang hanya dilakukan dengan mengadakan pertemuan dengan perwakilan masyarakat dan lembaga-lembaga terkait yang membahas pertanggungjawaban alokasi dana desa. Sedangkan masyarakat tidak mempunyai antusiasme dengan upaya yang dilakukan pemerintah desa tersebut.

\section{Peran Stakeholders dalam Pengelolaan Alokasi Dana Desa}

Terdapat beberapa stakeholders yang terlibat dalam pengelolaan alokasi dana desa yaitu kepala desa, karang taruna, tim penggerak PKK, masyarakat desa, dan Badan Permusyawaratan Desa (BPD). Stakeholders tersebut diharapkan mampu melaksanakan 
program tersebut secara tertib, efektif, efisien, serta dilakukan secara transparan dan dapat dipertanggungjawabkan secara teknis dan administratif.

Kepala desa selaku penanggungjawab kegiatan pengelolaan alokasi dana desa mempunyai beberapa peranan yang meliputi: (a) mengadakan sosialisasi pelaksanaan kegiatan alokasi dana desa, (b) membentuk tim pelaksana tingkat desa, (c) membuat Daftar Rencana Kegiatan (DRK) alokasi dana desa yang dilakukan bersama lembagalembaga terkait dan tokoh masyarakat, dan (d) mendampingi bendahara desa pada saat pencairan alokasi dana desa.

Stakeholders lainnya yaitu karang taruna dan tim penggerak PKK yang kontribusinya sama yaitu pada penyusunan Daftar Rencana Kegiatan (DRK) alokasi dana desa dan pelaksanaan kegiatan khususnya pada pembangunan infrastruktur. Selain itu, karang taruna melaksanakan penyelenggaraan pemberdayaan masyarakat terutama generasi muda dengan mendayagunakan sumber dan potensi tersebut untuk belanja perlengkapan olahraga dan seni sebagai penunjang kegiatan kepemudaan di desa. Sedangkan tim penggerak PKK melaksanakan penyelenggaraan masyarakat dengan mendayagunakan anggaran alokasi dana desa untuk kegiatan simpan pinjam ibu-ibu PKK sebagai upaya pelaksanaan program PKK yang berkaitan dengan kesejahteraan keluarga di desa.

Masyarakat desa yang nantinya akan memperoleh manfaat secara langsung dari adanya program ini dituntut untuk turut berperan serta dalam setiap tahapan pengelolaan alokasi dana desa. Namun, beberapa masyarakat bahkan masih belum mengetahui adanya program tersebut dikarenakan sosialisasinya yang tidak merata. Hal tersebut kemudian menyebabkan masyarakat menjadi acuh dan mempercayakan pelaksanaan pengelolaan alokasi dana desa kepada para tim pelaksana. Padahal seharusnya masyarakatlah yang paling mempunyai peranan dalam program tersebut karena kembali pada tujuan sesungguhnya yaitu pemberdayaan masyarakat.

Stakeholders lainnya yaitu Badan Permusyawaratan Desa (BPD), meskipun tidak memiliki kaitan kepentingan secara langsung BPD juga turut berperan dalam pengelolaan alokasi dana desa karena BPD mempunyai hak untuk melakukan pengawasan dan bersama dengan pemerintah desa bertanggung jawab dalam kegiatan tersebut. Peranan 
BPD lainnya yaitu turut berkontribusi pada tahap perencanaan penyusunan Daftar Rencana Kegiatana (DRK) alokasi dana desa dan turut serta bersama masyarakat bergotong royong dalam pelaksanaan pembangunan infrastruktur desa.

\section{Hasil-Hasil Pemberdayaan Masyarakat dari Anggaran Alokasi Dana Desa}

Pemberdayaan masyarakat diharapkan mampu menekankan pada 3 (tiga) komponen penting yaitu pemberdayaan lingkungan, pemberdayaan ekonomi, dan pemberdayaan manusia. Pemberdayaan lingkungan dialokasikan untuk pembangunan sarana/prasarana fisik yang dapat menunjang mobilitas masyarakat desa. masih ada beberapa poros jalan yang mulai rusak dan dianggap mengganggu akses perjalanan masyarakat setempat. Hal tersebut yang mendasari untuk menggunakan anggaran alokasi dana desa untuk pembangunan jalan skala kecil. Namun disisi lain, hal tersebut bertentang dengan makna pemberdayaan lingkungan yang sesungguhnya yaitu sebagai program perawatan dan pelestarian lingkungan. Alangkah baiknya jika biaya pemberdayaan lingkungan digunakan untuk penanaman pohon kembali atau penghijauan dan upaya pelestarian lingkungan lainnya.

Sedangkan pemberdayaan manusia dialokasikan untuk menunjang kegiatan kepemudaan melalui karang taruna yang digunakan untuk belanja perlengkapan olahraga dan seni. Pemberdayaan manusia lainnya digunakan untuk menunjang program PKK yaitu kegiatan simpan pinjam yang berkaitan dengan kesejahteraan keluarga di desa.

Anggaran pemberdayaan tersebut masih didominasi bantuan dari pemerintah, sedangkan swadaya masyarakat masih belum nampak. Pemberdayaan manusia dapat dikatakan masih sebatas dana dari pemerintah untuk rakyat. Jadi dapat ditarik kesimpulan bahwa pemberdayaan manusia dikategorikan sebagai pemberdayaan yang berupa support dan pemberdayaan tersebut belum menyentuh pemberdayaan yang sesungguhnya yaitu pemberdayaan emansipatoris dimana dana pemberdayaan bersumber dari masyarakat yang digunakan oleh masyarakat itu sendiri.

\section{Faktor Penghambat dan Faktor Pendukung Pengelolaan Alokasi Dana Desa}

\section{a. Faktor Penghambat}

Faktor penghambat dalam pelaksanaan kegiatan alokasi dana desa yaitu budaya paternalistik yang masih melekat pada masyaraka sehingga mereka 
cenderung bersikap acuh dan memberikan kepercayaan sepenuhnya kepada kepala desa. Hal tersebut menyebabkan tidak semua masyarakat tahu tentang adanya program pengelolaan alokasi dana desa tersebut dan juga mengakibatkan rendahnya pengawasan dari masyarakat dalam pelaksanaan kegiatan tersebut. Padahal pengawasan dari masyarakat sangat diperlukan untuk menghindari halhal yang tidak diinginkan terjadi.

Selain itu, dominasi pihak kecamatan dalam penyusunan Surat Pertanggung Jawaban (SPJ) alokasi dana dianggap dapat menghambat kemandirian desa. Padahal tugas dari tim pengendali kecamatan hanya melakukan bimbingan teknis administrasi keuangan kepada tim pelaksana tingkat desa.

\section{b. Faktor Pendukung}

Berdasarkan hasil penelitian dan pengamatan yang telah dilakukan, diketahui bahwa faktor-faktor yang mendukung pelaksanaan kegiatan alokasi dana desa yaitu adanya peraturan perundang-undangan yang jelas sehingga tim pelaksana dapat melakukan tugasnya dengan baik. Peraturan perundangundangan yang ada juga memudahkan tim pelaksana untuk membagi anggaran alokasi dana desa disetiap pos-posnya.

Selain itu, tingkat partisipasi masyarakat dalam pelaksanaan kegiatan juga sangat tinggi. Hal tersebut dibuktikan dengan budaya gotong royong masyarakat yang sangat baik, khususnya pada tahap pelaksanaan. Dengan diberdayakannya masyarakat melalui gotong royong secara tidak langsung pemerintah desa memberikan bimbingan dan dukungan agar masyarakat mampu menjalankan perannya agar kemudian tidak terjatuh ke dalam posisi yang lemah dan terpinggirkan.

\section{KESIMPULAN DAN SARAN}

Simpulan dan saran dapat dibuat dalam sub bagian yang terpisah. Simpulan menjawab tujuan, menyatakan hasil penelitian secara ringkas, juga bukan angka-angka atau kalimat statistik. Saran merupakan penelitian lanjutan yang dirasa masih diperlukan untuk penyempurnaan hasil penelitian supaya berdaya guna. 


\section{REFERENSI}

Adisasmita, Rahardjo. (2013). Pembangunan Perdesaan: Pendekatan Partisipatif, Tipologi, Strategi, Konsep Desa Pusat Pertumbuhan. Yogyakarta, Graha Ilmu.

Peraturan Pemerintah Nomor 72 Tahun 2005 Tentang Desa (c. 3) Jakarta.

Kementerian Dalam Negeri (2007) Kader Pemberdayaan Masyarakat. Jakarta, Menteri Dalam Negeri.

Kementerian Dalam Negeri (2007) Pedoman Pengelolaan Keuangan Desa. Jakarta, Menteri Dalam Negeri.

Rozaki, Abdur, dkk. (2005). Prakarsa Desentralisasi dan Otonomi Desa. Yogyakarta, IRE Press.

Siagian, Sondang. (1990). Filsafat Administrasi. Cet. 21. Jakarta: CV. Haji Masagung

Sumaryadi, I Nyoman. (2005). Perencanaan Pembangunan Daerah Otonom dan Pemberdayaan Masyarakat. Jakarta, Citra Utama.

Sugiyono. 2008. Metode Penelitian Kuantitatif Kualitatif dan R\&D. Bandung, Alfabeta. Sumodiningrat, Gunawan. (1999). Pemberdayaan Masyarakat dan Jaring Pengaman Sosial. Jakarta, Gramedia Pustaka Umum.

The Liang Gie. (1987). Pengertian, Kedudukan, dan Perincian Ilmu Administrasi. Yogyakarta, Yayasan Studi Ilmu dan Teknologi.

Undang Undang Nomor 32 Tahun 2004 Tentang Pemerintahan Daerah (c.1) Jakarta, Direktorat Jenderal Otonomi Daerah. 